\title{
PREDIKSI PENJUALAN PAPAN BUNGA MENGGUNAKAN METODE DOUBLE EXPONENTIAL SMOOTHING
}

\author{
M Hafizd Elison ${ }^{(1)}$, Rudy Asrianto, M.Kom ${ }^{(2)}$, Aryanto, SE, MIT. AK ${ }^{(3)}$ \\ ${ }^{1)}$ Mahasiswa Program Studi Sistem Informasi \\ ${ }^{2,3)}$ Dosen Program Studi Sistem Informasi \\ Fakultas Ilmu Komputer Universitas Muhammadiyah Riau \\ e-mail: hafizdmuhammad1996@gmail.com
}

\begin{abstract}
ABSTRAK
Untuk mendapatkan laba yang besar dalam suatu bentuk usaha adalah dengan menentukan prediksi penjualan pada bulan berikutnya. Prediksi merupakan salah satu kunci dari keberhasilan penjualan karena dengan nilai prediksi penjualan yang bisa dijadikan panduan sebagai acuan untuk menentukan suatu penjualan produk. Metode Double Exponential Smoothing digunakan untuk menentukan prediksi penjualan pada periode berikutnya. Metode Double Exponential Smoothing merupakan metode peramalan yang cukup baik untuk peramalan jangka panjang, jangka menengah maupun jangka pendek, terutama pada tingkat operasional suatu bentuk usaha, dalam perkembangan dasar matematis dari metode Double Exponential Smoothing. Data yang akan diolah adalah data pada Toko Papan Bunga Djaya Florist pada tahun januari 2017 - Desember 2019 dan disajikan pada data perbulan. Hasil yang didapatkan dari penelitian ini adalah hasil analisa dari metode eksponensial untuk memperoleh informasi prediksi penjualan dan tingkat keakuratannya dengan MAPE untuk mencari error terkecil.
\end{abstract}

Kata Kunci: Prediksi, Penjualan, Papan bunga, Double Exponential Smoothing

\begin{abstract}
To get a large profit in a form of business is to determine sales predictions in the following month. Prediction is one of the keys to sales success because the sales prediction value can be used as a guide as a reference for determining a product sale. The Double Exponential Smoothing method is used to determine sales predictions for the next period. The Double Exponential Smoothing method is a pretty good forecasting method for long-term, medium-term and short-term forecasting, especially at the operational level of a business, in the mathematical basis of the Double Exponential Smoothing method. The data to be processed is data at the Bunga Bunga Djaya Florist Shop in January 2017 - December 2019 and presented in monthly data. The results obtained from this study are the results of the analysis of the exponential method to obtain sales prediction information and its level of accuracy with MAPE data to find the smallest error.
\end{abstract}

Keywords: Prediction, Sales, Flower Board, Double Exponential Smoothing

\section{Pendahuluan}

Prediksi merupakan suatu bagian yang sangat diperlukan karena kegiatan prediksi biasanya digunakan untuk pengambilan keputusan manajemen setiap organisasi maupun dalam bentuk usaha yang digunakan untuk menentukan sasaran dan tujuannya.

Oleh karena itu kegiatan prediksi merupakan suatu dugaan atau prakiraan terhadap permintaan untuk masa depan, selain itu prediksi yang digunakan untuk perencanaan dan penyusunan suatu kegiatan dimasa yang akan datang dapat juga dilakukan dengan menggunakan data lampau, yang mana data lampau tersebut akan dilakukan sebuah analisa ilmiah, khususnya dengan menggunakan sebuah metode yang statistika.

Penjualan merupakan salah satu indikator paling penting dalam sebuah perusahaan. Dimana didalam penjualan juga ada kepuasan konsumen yang merupakan isu yang kritikal di semua industri baik jasa dan perdagangan. Salah satunya adalah kepuasan konsumen terhadap pemesanan papan bunga di Indonesia khusus nya di Pekanbaru, para produsen papan bunga dituntut menyediakan produk papan bunga yang sesuai dengan kebutuhan konsumen, produk yang dimaksud adalah produk yang mampu menyuguhkan desain menarik, dan mempunyai kreativitas yang berkualitas. Setiap toko papan bunga selalu berharap bahwa produknya dapat diterima oleh pasar dan dapat memberikan persepsi konsumen yang baik terhadap produk yang ditawarkan pihak toko.

Pada toko papan bunga Djaya Florist terdapat berbagai macam ucapan papan bunga yaitu ucapan selamat, ucapan duka cita, ucapan pernikahan, dan ucapan selamat wisuda. Jadi permasalahan yang ada adalah, permintaan yang banyak dari pelanggan menyebabkan persediaan papan bunga mengalami kekurangan stock papan yang ada. Penjualan papan bunga ini tidak bisa diukur secara normal, sehingga pemesanan tidak dapat di prediksi dikarenakan pemesanan papan bunga juga bisa mengalami kenaikan atau bisa mengalami penurunan. Hal ini mengakibatkan hilangnya peluang untuk mendapatkan keuntungan, karena bisa saja konsumen membeli di toko papan bunga lain. Masalah tersebut terjadi dikare- 
nakan persediaan stock papan bunga yang kurang baik akibat dari kurang akuratnya penentuan persediaan terhadap papan bunga sulit untuk menentukan berapa banyak stock papan yang harus disiapkan untuk memenuhi permintaan konsumen.

Dengan permasalahan tersebut, maka dengan penelitian ini akan di bangun suatu perhitungan yang berbentuk program bantu yang dapat memprediksi penjualan papan bunga berdasarkan riwayat penjualan sebelumnya, maka membantu pemilik papan bunga dalam mengambil suatu keputusan, dalam penambahan stock papan bunga dan maintenance beberapa papan yang ada. Model prediksi yang digunakan dalam melakukan prediksi jumlah persediaan stock papan bunga ini adalah time series atau bisa disebut deret waktu, dan metode prediksi yang digunakan adalah double exponential smoothing. Metode ini tergolong dalam metode time series yang mempergunakan data masa lalu untuk memprediksi sesuatu dimasa yang akan datang. Metode double exponential smoothing digunakan jika data masa lalu merupakan data yang memiliki unsur trend. Metode double exponential smoothing dirasa cocok karena menggunakan data-data histori yang sudah ada. Metode prediksi tersebut selanjutnya akan dilakukan perhitungan dengan membandingan nilai error terkecil dari metode prediksi tersebut. Hasil perhitungan tersebut diperoleh melalui evaluasi dan validasi dari metode tersebut menggunakan metode MAPE (Mean Absolute Percentage Error).

\section{MODEL TIME SERIES}

Langkah penting memilih suatu metode deret waktu yang tepat adalah dengan mempertimbangkan jenis pola data, sehingga dengan metode yang paling tepat dengan pola data tersebut dapat diuji. Pola data dibedakan menjadi empat jenis, yaitu:

1. Pola Trend (T), yaitu terjadi apabila terdapat kenaikan atau penurunan jangka panjang dalam data. Pola trend dapat ditunjukkan pada Gambar 2.1

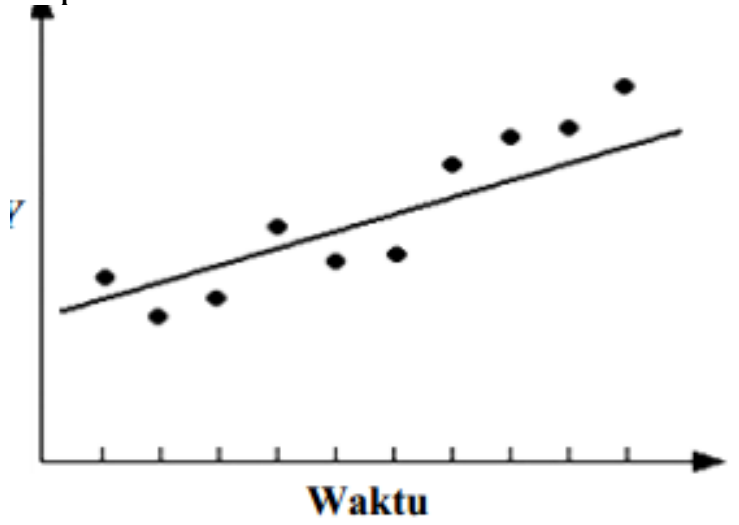

Gambar 2.1 Pola Trend

2. Pola Siklis $(\mathrm{C})$, yaitu terjadi apabila datanya dipengaruhi oleh frekuensi ekonomi jangka panjang dan berhubungan dengan siklus bisnis. Pola siklis dapat dilihat pada Gambar 2.2

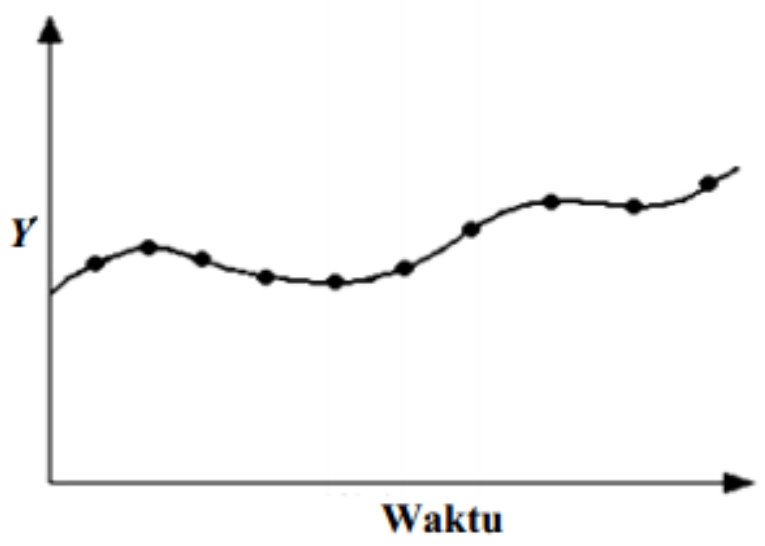

Gambar 2.2 Pola Siklis 
3. Pola Musiman (S), yaitu terjadi apabila suatu deret dipengaruhi oleh faktor musiman. Disebut musiman karena permintaan ini biasanya dipengaruhi oleh musim sehingga interval perulangan data ini adalah satu tahun. Berikut pola data musiman pada Gambar 2.3

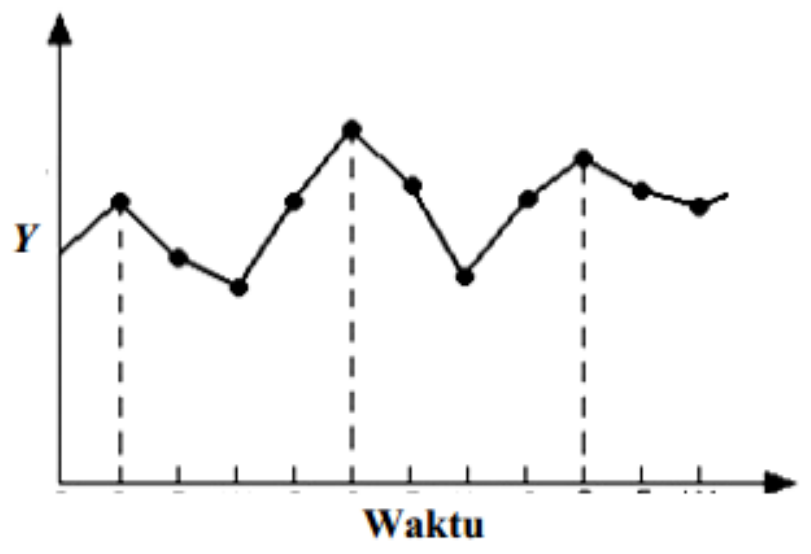

Gambar 2.3 Pola Musiman

4. Pola Horizontal $(\mathrm{H})$, terjadi apabila nilai data berfluktuasi di sekitar nilai rata -rata yang konstan. Suatu produk yang penjualannya tidak meningkat atau menurun selama waktu tertentu termasuk jenis pola ini. Pada pola data Horizontal terdapat pada Gambar 2.4.

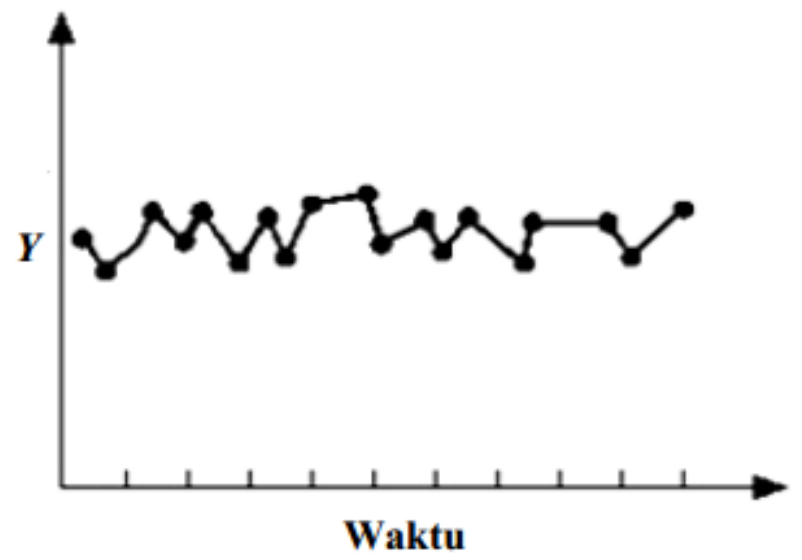

Gambar 2.4 Pola Horizontal

Analisis deret waktu dapat digunakan karena dengan mengamati data deret waktu akan terlihat komponen-komponen yang mempengaruhi suatu pola data masa lalu dan sekarang, yang cenderung berulang dimasa mendatang. Dari analisis deret waktu dapat diperoleh ukuran - ukuran yang dapat digunakan untuk prediksi. Metode ini didasarkan pada asumsi bahwa pola lama akan terulang.

\section{MEtode Penelitian}

\section{A. DOUBLE EXPONENTIAL SMOOTHING}

Dasar pemikiran dari metode exponential smoothing tunggal maupun ganda adalah bahwa nilai pemulusan akan terdapat pada waktu sebelum data sebenarnya apabila pada data tersebut terdapat komponen trend. Oleh karena itu untuk nilai-nilai pemulusan tunggal perlu ditambahkan nilai pemulusan ganda untuk menyesuaikan trend. Metode Exponential Smoothing ganda yang dapat digunakan untuk menyelesaikan trend linier adalah metode dua parameter dari Holt. Pada metode Holt nilai trend tidak dimuluskan dengan pemulusan ganda secara langsung, tetapi proses pemulusan trend dilakukan dengan menggunakan parameter yang berbeda dengan parameter yang digunakan pada pemulusan data asli. (Baktiar et al., 2013). 
1. Menentukan smoothing pertama

$$
S^{1}=\alpha X_{t}+(1-\alpha) S^{1} t-1
$$

2. Menentukan smoothing kedua

$$
S^{2}=\alpha S^{1}+(1-\alpha) S^{2} t-1
$$

3. Menentukan besarnya kostanta $\mathrm{A}$

$$
a_{t}=\alpha X_{t}+\left(S^{1}{ }_{t}-S^{2}{ }_{t}\right)=2 S^{1}{ }_{t}-S^{2}{ }_{t}
$$

4. Menentukan besarnya slope

$$
b_{t}=\frac{\alpha}{1-\alpha}\left(S_{t}^{1}-S^{2}{ }_{t}\right)
$$

5. Menentukan besarnya forecast

$F_{t+m}=a_{t}+b_{t} m$

\section{B. Mean Absolute Percentage Error (MAPE)}

MAPE merupakan ukuran kesalahan relatif, MAPE biasanya lebih berarti bila dibandingkan dengan MAD, karena MAPE menyatakan persentase kesalahan hasil prediksi terhadap permintaan aktual selama periode tertentu yang akan memberikan informasi persentase kesalahan terlalu tinggi atau terlalu rendah. Secara sistematis, rumus MAPE dinyatakan sebagai berikut:

MAPE $=\left(\frac{100}{n}\right) \sum|\mathrm{PE}|$.

Persentase error merupakan kesalahan persentase dari suatu prediksi

$\mathrm{PE}=X_{t}-\frac{F_{t}}{X t}$

Dimana :

At $=$ Permintaan aktual pada periode $t$

$\mathrm{Ft}=$ Prediksi permintaan pada periode $\mathrm{t}$

$\mathrm{n}=$ Jumlah periode prediksi yang terlibat

\section{AnAlisa Data}

Adapun data yang digunakan dalam penganalisisan data adalah hasil penjualan papan bunga Djaya Florist pada periode tahun 2017, 2018, dan 2019. Dapat dilihat pada tabel 4.1 stok penjualan papan bunga pada toko Djaya Florist.

\begin{tabular}{lccc}
\hline \multicolumn{1}{c}{ Bulan } & \multicolumn{3}{c}{ Tahun } \\
\cline { 2 - 4 } Januari & 2017 & 2018 & 2019 \\
Februari & 72 & 65 & 70 \\
Maret & 90 & 95 & 72 \\
April & 85 & 105 & 120 \\
Mei & 70 & 60 & 60 \\
Juni & 61 & 64 & 65 \\
Juli & 74 & 78 & 70 \\
Agustus & 90 & 87 & 75 \\
September & 120 & 90 & 110 \\
Oktober & 80 & 75 & 105 \\
November & 88 & 80 & 80 \\
Desember & 90 & 76 & 85 \\
\hline Sumber : Toko Papan Bunga Djaya Florist
\end{tabular}

Dari data diatas akan dijadikan plot grafik supaya dapat dianalisa, apakah plot data yang terjadi berupa trend, musiman, horizontal, siklis, atau stationer. Plot data trend ada dua yaitu trend naik atau trend turun. Trend turun setiap perperiode mengalami penurunan, sebaliknya dengan trend naik data perperiode nya mengalami kenaikan. Berikut plot data dari penjualan papan bunga tahun 2017, 2018, dan 2019 pada gambar 4.1 


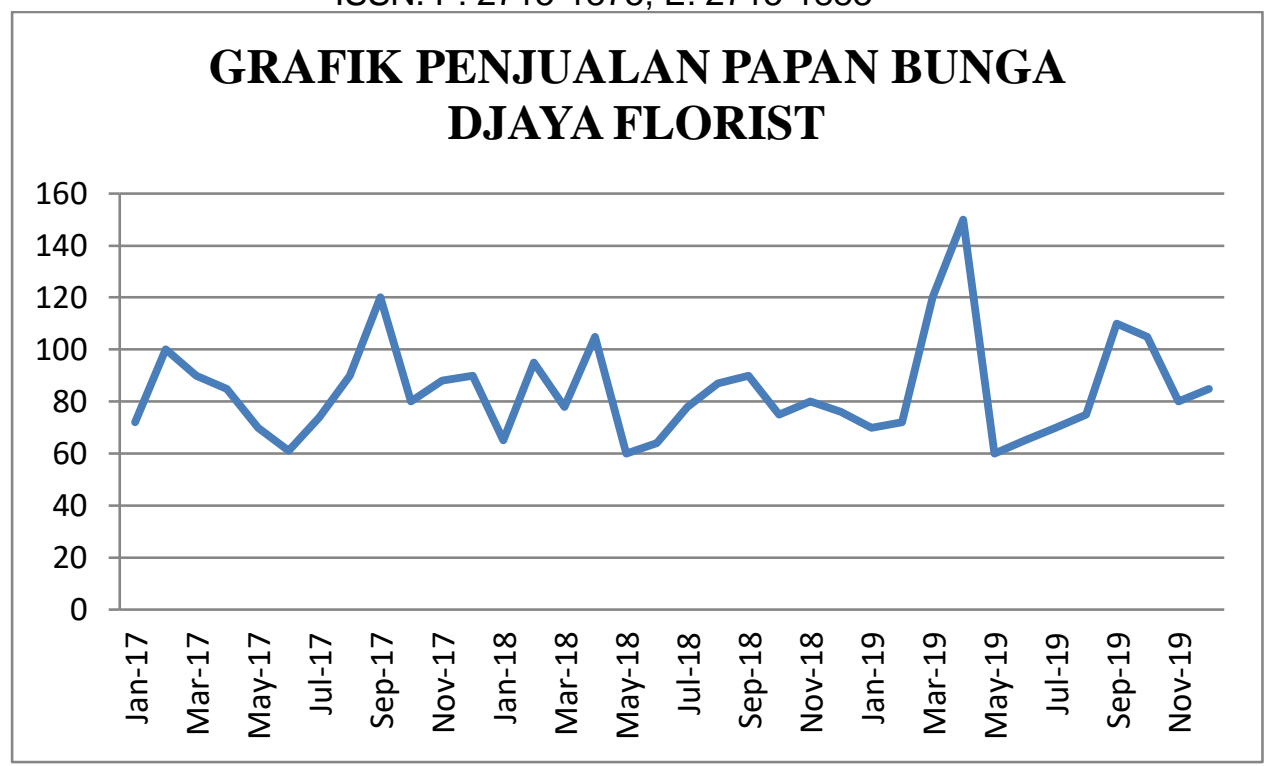

Gambar 4.1 Plot Data Penjualan Papan Bunga Periode 2017 - 2019

Dari pola yang ada diatas dapat dilihat data periode 2017 penjualan papan bunga mengalami penurunan pada bulan Maret hingga bulan Juni dan mengalami kenaikan di bulan Juli hingga bulan September. Pada periode 2018 penjualan papan bunga mengalami kenaikan di bulan Januari hingga Februari dan mengalami penurunan kembali pada bulan April hingga Juni. Dan pada periode tahun 2019 data penjualan papan bunga mengalami kenaikan di bulan Januari hingga April dan kembali mengalami penurunan yang sangat drastis dibulan Mei. Sehingga pola data seperti itu bisa dikatakan pola data tren turun dan pola data tren naik, sehingga dapat dianalisis menggunakan metode Double Exponential Smoothing.

Perhitungan dibawah ini menggunakan data penjualan papan bunga pada periode Januari 2017 Desember 2019 dengan diganti periode bulan menjadi $(\mathrm{t})$.

A. Langkah pertama penggunaan metode Double Exponential Smoothing adalah menentukan smoothing pertama. Konstanta yang digunakan dalam perhitungan ini yaitu nilai alpha $(\alpha=0.6)$.

Rumus untuk menentukan Smoothing pertama (1) :

$$
S^{\prime}=\alpha X_{t}+(1-\alpha) S^{\prime} t-1
$$

1. Untuk $\mathrm{t}=1$

Karena pada $S_{t-1}^{\prime}$ pada $t=1$ belum tersedia, maka untuk mengatasi masalah ini dapat dilakukan dengan menetapkan nilai $S_{t}^{\prime}$ pada $t=1$ sama dengan data periode $\left(x_{t}\right)$ sebesar 72

2. Untuk $\mathrm{t}=2$

Yang dimana untuk mencari smooting pertama pada $\mathrm{t}=2$ untuk nilai $\mathrm{S}_{\mathrm{t}-1}$ dapat diambil dari hasil nilai smoothing pertama pada $\mathrm{t}=1$ dengan penyelesaian sebagai berikut :

$$
\begin{aligned}
\mathrm{S}_{2}{ }_{2} & =\alpha \mathrm{X}_{2}+(1-\alpha) \mathrm{S}_{2-1} \\
& =(0,6 \times 100)+(1-0,6) 72 \\
& =89
\end{aligned}
$$

3. Untuk $\mathrm{t}=3$

Yang dimana untuk mencari smoothing pertama pada $\mathrm{t}=3$ untuk nilai $\mathrm{S}_{\mathrm{t}-1}$ dapat diambil dari hasil nilai smoothing pertama pada $\mathrm{t}=2$ dengan penyelesaian sebagai berikut :

$$
\begin{aligned}
\mathrm{S}_{3} & =\alpha \mathrm{X}_{3}+(1-\alpha) \mathrm{S}_{3-1} \\
& =(0,6 \times 90)+(1-\alpha) 89 \\
& =90
\end{aligned}
$$

Dan seterusnya sampai perhitungan $\mathrm{S}_{\mathrm{t}}$ untuk $\mathrm{t}=36$ yaitu sebagai berikut :

4. Untuk $\mathrm{t}=36$

Yang dimana untuk mencari smoothing pertama pada $\mathrm{t}=36$ untuk $\mathrm{S}_{\mathrm{t}-1}^{\prime}$ dapat diambil dari hasil nilai smoothing pertama pada $\mathrm{t}=35$ dengan penyelesaian sebagai berikut : 


$$
\begin{aligned}
\mathrm{S}_{36} & =\alpha \mathrm{X}_{36}+(1-\alpha) \mathrm{S}_{36-1} \\
& =(0,6 \times 85)+(1-\alpha) 88 \\
& =86
\end{aligned}
$$

Hasil dari perhitungan selengkapnya dapat dilihat pada tabel 4.2

B. Langkah kedua penggunaan metode Double Exponential Smoothing adalah menentukan smoothing kedua. Konstanta yang digunakan dalam perhitungan ini yaitu nilai alpha $(\alpha=0.6)$.

Rumus untuk menentukan smoothing kedua (2) :

1. Untuk $\mathrm{t}=1$

$$
S^{\prime \prime}=\alpha S_{t}^{1}+(1-\alpha) S^{\prime \prime} t-1
$$

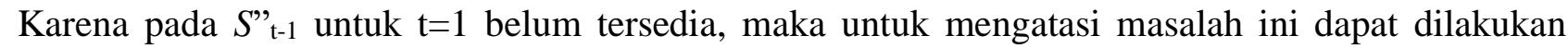
dengan menetapkan nilai $S$ " ${ }_{t}$ pada $t=1$ sama dengan nilai data periode $\left(X_{t}\right)$ sebesar 72

2. Untuk $\mathrm{t}=2$

Yang dimana untuk mencari nilai smoothing kedua pada $t=2$ untuk nilai $S_{t}^{\prime}$ pada rumus didapat dari hasil perncarian smoothing pertama pada $\mathrm{t}=2$ sedangkan untuk $\mathrm{S}$ " ${ }_{\mathrm{t}-1}$ didapatkan dari hasil pencarian smoothing kedua pada $\mathrm{t}=1$ dengan penyelesaian sebagai berikut :

$$
\begin{aligned}
\mathrm{S}_{2}{ }_{2} & =\alpha \mathrm{S}{ }_{2}+(1-\alpha) \mathrm{S}{ }_{2-1} \\
& =(0,6 \times 89)+(1-\alpha) 72 \\
& =82
\end{aligned}
$$

3. Untuk $\mathrm{t}=3$

Yang dimana untuk mencari nilai smoothing kedua pada $t=3$ untuk nilai $S^{\prime}$ pada rumus didapat dari hasil pencarian smoothing pertama pada $\mathrm{t}=3$ sedangkan untuk $\mathrm{S}_{\mathrm{t}-1}$ didapatkan dari hasil pencarian smoothing kedua pada $\mathrm{t}=2$ dengan penyelesaian sebagai berikut :

$$
\begin{aligned}
\mathrm{S}_{3} & =\alpha \mathrm{S}_{3}+(1-\alpha) \mathrm{S}{ }_{3-1} \\
& =(0,6 \times 90)+(1-\alpha) 82 \\
& =87
\end{aligned}
$$

Dan seterusnya sampai pada perhitungan $S{ }^{\prime}$ untuk $\mathrm{t}=36$ yaitu sebagai berikut:

4. Untuk $\mathrm{t}=36$

Yang dimana untuk mencari nilai smoothing kedua pada $t=36$ untuk nilai $S^{\prime}$ t pada rumus didapat dari hasil pencarian smoothing pertama pada $\mathrm{t}=36$ sedangkan untuk $\mathrm{S}_{\mathrm{t}-1}$ didapatkan dari hasil pencarian smoothing kedua pada $\mathrm{t}=35$ dengan penyelesaian sebagai berikut :

$$
\begin{aligned}
\mathrm{S}_{36}{ }_{36} & =\alpha \mathrm{S}_{36}+(1-\alpha) \mathrm{S}{ }_{36-1} \\
& =(0,6 \times 86)+(1-\alpha) 91 \\
& =88
\end{aligned}
$$

Hasil dari perhitungan selengkapnya dapat dilihat pada tabel 4.2

C. Langkah ketiga penggunaan metode Double Exponential Smoothing adalah menentukan besarnya nilai $\alpha_{t}$. Konstanta yang digunakan dalam perhitungan ini yaitu nilai alpha $(\alpha=0.6)$.

Rumus untuk menentukan nilai $\alpha_{\mathrm{t}}$ :

1. Untuk $\mathrm{t}=1$

$$
a_{t}=2 S^{1}{ }_{t}-S^{2}{ }_{t}
$$

Yang dimana untuk mencari nilai $\alpha_{\mathrm{t}}$ pada $\mathrm{t}=1$ yaitu nilai 2 dikalikan dengan hasil dari nilai smoothing pertama (S') dikurangi dengan hasil dari nilai smoothing kedua (S") pada periode $t=1$, penyelesaiannya sebagai berikut

$$
\begin{aligned}
\alpha_{1} & =2 S^{\prime}{ }_{1}-S^{\prime}{ }_{1} \\
& =(2 \times 72)-72 \\
& =72
\end{aligned}
$$

2. Untuk $\mathrm{t}=2$

Yang dimana untuk mencari nilai $\alpha_{\mathrm{t}}$ pada $\mathrm{t}=1$ yaitu nilai 2 dikalikan dengan hasil dari nilai smoothing pertama (S') dikurangi dengan hasil dari nilai smoothing kedua (S') pada periode $t=2$, penyelesaiannya sebagai berikut

$$
\begin{aligned}
\alpha_{2} & =2 S^{\prime}{ }_{2}-S^{\prime}{ }_{2} \\
& =(2 \times 89)-82 \\
& =96
\end{aligned}
$$


3. Untuk $\mathrm{t}=3$

Yang dimana untuk mencari nilai $\alpha_{\mathrm{t}}$ pada $\mathrm{t}=1$ yaitu nilai 2 dikalikan dengan hasil dari nilai smoothing pertama (S') dikurangi dengan hasil dari nilai smoothing kedua (S') pada periode $t=3$, penyelesaiannya sebagai berikut

$$
\begin{aligned}
\alpha_{3} & =2 S^{\prime}{ }_{3}-S^{\prime}{ }_{3} \\
& =(2 \times 90)-87 \\
& =93
\end{aligned}
$$

Dan seterusnya sampai pada perhitungan $\alpha_{\mathrm{t}}$ untuk $\mathrm{t}=36$ yaitu sebagai berikut :

4. Untuk $\mathrm{t}=36$

Yang dimana untuk mencari nilai $\alpha_{\mathrm{t}}$ pada $\mathrm{t}=1$ yaitu nilai 2 dikalikan dengan hasil dari nilai smoothing pertama (S') dikurangi dengan hasil dari nilai smoothing kedua (S') pada periode $\mathrm{t}=36$, penyelesaiannya sebagai berikut

$$
\begin{aligned}
\alpha_{36} & =2 S^{\prime}{ }_{36}-S^{\prime}{ }_{36} \\
& =(2 \times 86)-88 \\
& =84
\end{aligned}
$$

Hasil dari perthitungan $\alpha_{\mathrm{t}}$ selengkapnya dapat dilihat pada tabel 4.2

D. Langkah keempat penggunaan metode Double Exponential Smoothing adalah menentukan besarnya nilai $b_{t}$. Konstanta yang digunakan dalam perhitungan ini yaitu nilai alpha $(\alpha=0.6)$.

Rumus untuk menentukan nilai $b_{t}$ :

1. Untuk $\mathrm{t}=1$

$$
b_{t}=\frac{\alpha}{1-\alpha}\left(S_{t}^{1}-S^{2}{ }_{t}\right.
$$

Yang untuk mencari nilai nilai $b_{t}$ dengan menentukan nilai $\frac{\alpha}{1-\alpha}$ yang dikalikan dengan hasil dari smoothing pertama (S') kemudian dikurangi dengan hasil dari nilai smoothing kedua (S') pada $\mathrm{t}=1$, yang penyelesaian nya dapat dilihat sebagai berikut :

$$
\begin{aligned}
b_{1} & =\frac{\alpha}{1-\alpha}\left(S^{\prime}{ }_{1}-S^{\prime \prime}{ }_{1}\right) \\
& =\frac{0,6}{1-0,6}(72-72) \\
& =0
\end{aligned}
$$

2. Untuk $\mathrm{t}=2$

Yang untuk mencari nilai nilai $b_{t}$ dengan menentukan nilai $\frac{\alpha}{1-\alpha}$ yang dikalikan dengan hasil dari smoothing pertama (S') kemudian dikurangi dengan hasil dari nilai smoothing kedua (S') pada $\mathrm{t}=2$, yang penyelesaian nya dapat dilihat sebagai berikut :

$$
\begin{aligned}
b_{2} & =\frac{\alpha}{1-\alpha}\left(S_{2}^{\prime}-S_{2}{ }_{2}\right) \\
& =\frac{0,6}{1-0,6}(89-82) \\
& =10,5
\end{aligned}
$$

3. Untuk $\mathrm{t}=3$

Yang untuk mencari nilai nilai $b_{t}$ dengan menentukan nilai $\frac{\alpha}{1-\alpha}$ yang dikalikan dengan hasil dari smoothing pertama (S') kemudian dikurangi dengan hasil dari nilai smoothing kedua (S') pada $\mathrm{t}=3$, yang penyelesaian nya dapat dilihat sebagai berikut :

$$
\begin{aligned}
b_{3} & =\frac{\alpha}{1-\alpha}\left(S^{\prime}{ }_{3}-S^{\prime \prime}{ }_{3}\right) \\
& =\frac{0,6}{1-0,6}(90-87) \\
& =0
\end{aligned}
$$

Dan seterusnya sampai pada perhitungan $b_{\mathrm{t}}$ untuk $\mathrm{t}=36$ yaitu sebagai berikut :

4. Untuk $\mathrm{t}=36$ 
JURSISTEKNI (Jurnal Sistem Informasi dan Teknologi Informasi) Vol 2, No.3, September 2020: Hal 45 - 56 ISSN. P: 2715-1875, E: 2715-1883

Yang untuk mencari nilai nilai $b_{t}$ dengan menentukan nilai $\frac{\alpha}{1-\alpha}$ yang dikalikan dengan hasil dari smoothing pertama (S') kemudian dikurangi dengan hasil dari nilai smoothing kedua (S") pada $\mathrm{t}=36$, yang penyelesaian nya dapat dilihat sebagai berikut :

$$
\begin{aligned}
b_{36} & =\frac{\alpha}{1-\alpha}\left(S^{\prime}{ }_{36}-S^{\prime \prime}{ }_{36}\right) \\
& =\frac{0,6}{1-0,6}(86-88) \\
& =-3
\end{aligned}
$$

Hasil perhitungan $b_{t}$ selengkapnya dapat dilihat pada tabel 4.2

Setelah dilakukan perhitungan nilai smoothing pertama, nilai smoothing kedua, nilai $a_{\mathrm{t}}$ dan nilai $b_{\mathrm{t}}$ dengan menggunakan nilai alpha $=0,6$ maka diperoleh hasil perhitungan secara lengkap pada tabel 4.2

Tabel 4.2 hasil perhitungan Double Exponential Smoothing nilai alpha $=0,6$

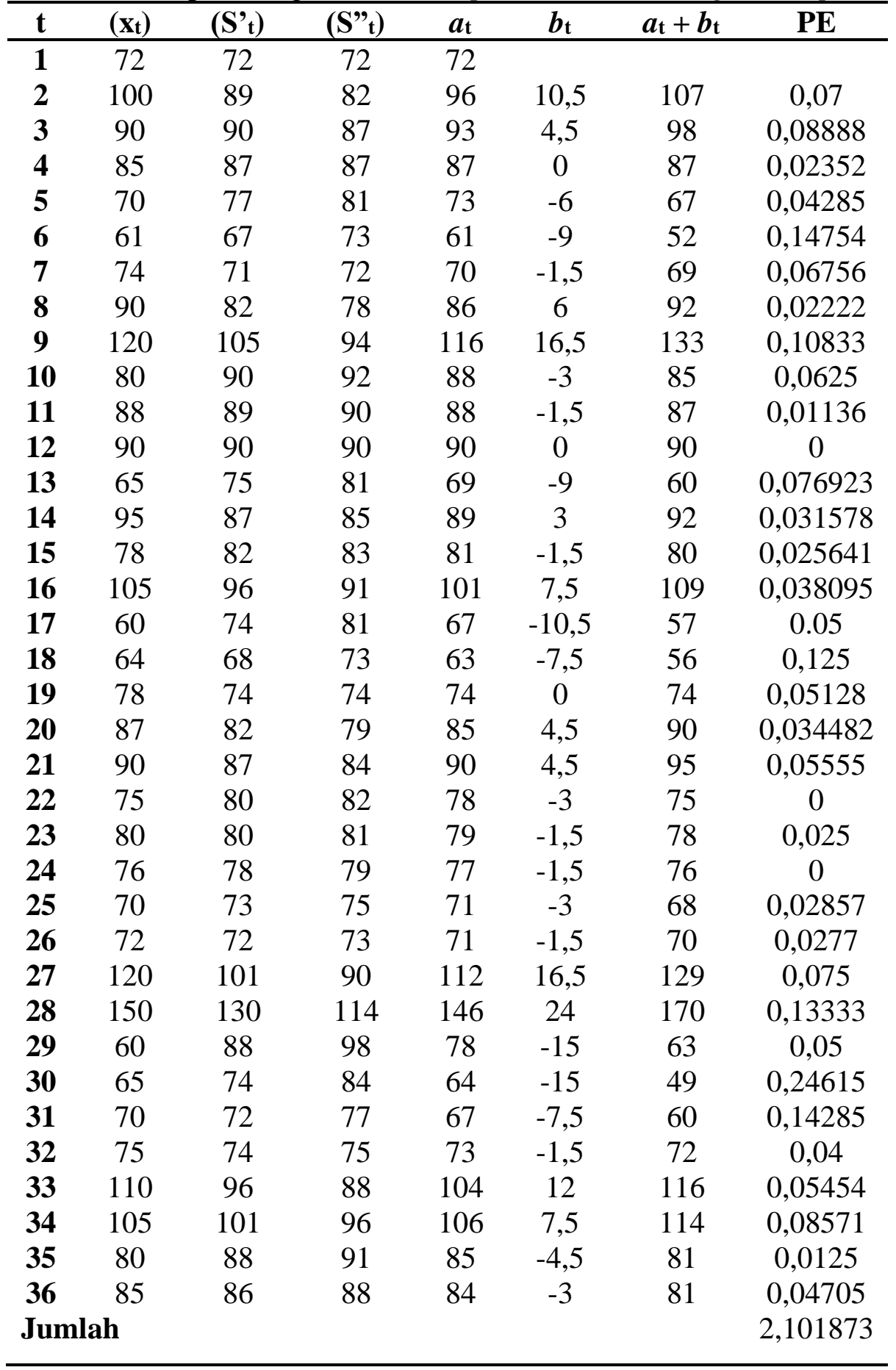


E. Menentukan Nilai Ketepatan Prediksi

Setelah ditentukan hasil dari rumus perhitungan double exponential smoothing pada tabel 4.2 dengan alpha $=0,6$ untuk melihat hasil perhitungan seluruhnya. Untuk menentukan hasil dari MAPE dicari terlebih dahulu hasil dari PE (Percentage Error) setiap periode $(\mathrm{t})$, dengan rumus $\left(X_{t}-\frac{F_{t}}{X t}\right)$. Kemudian untuk nilai PE (Percentage Error) harus dijumlahkan mendapatkan hasil yaitu 2,101873. Hasil dari PE ini akan dihitung menggunakan rumus Mean Absolute Percentage Error (MAPE) untuk mencari nilai $\alpha$ (alpha) error terkecil dengan rumus persamaan (6). Penyelesaian nya adalah sebagai berikut.

Untuk $\alpha=0,6$ dan $\mathrm{n}=36$, dimana nilai $(\mathrm{n})$ didapat dari data jumlah periode $(\mathrm{t})$, maka :

$$
\begin{aligned}
\text { MAPE } & =\left(\frac{100}{n}\right) \sum|P E| \\
& =\left(\frac{100}{36}\right) \times 2,101873 \\
& =5,84 \%
\end{aligned}
$$

Nilai alpha $(\alpha)$ yang telah ditentukan adalah $0.1,0.2,0.3,0.4,0.5,0.6,0.7,0.8$, dan 0.9. Hasil perhitungan Mean Absolute Percentage Error (MAPE) untuk parameter $\alpha=0.1$ sampai $\alpha=0.9$ dapat dilihat

\begin{tabular}{|c|c|}
\hline $\begin{array}{c}\text { Parameter } \\
\alpha\end{array}$ & $\begin{array}{c}\text { Mean } \\
\text { Absolute } \\
\text { Percentage } \\
\text { Error (MAPE) }\end{array}$ \\
\hline 0.1 & $15,56 \%$ \\
\hline 0.2 & $13,47 \%$ \\
\hline 0.3 & $10,46 \%$ \\
\hline 0.4 & $7,35 \%$ \\
\hline 0.5 & $5,45 \%$ \\
\hline 0.6 & $5,84 \%$ \\
\hline 0.7 & $8,98 \%$ \\
\hline 0.8 & $13,06 \%$ \\
\hline 0.9 & $15,28 \%$ \\
\hline
\end{tabular}
pada Tabel 4.3

Tabel 4.3 Nilai MAPE untuk parameter $\alpha=0.1$ sampai $\alpha=0.9$

F. Hasil Prediksi Papan Bunga Djaya Florist

Setelah dilakukan perhitungan nilai smoothing pertama, nilai smoothing kedua, nilai $\alpha^{\mathrm{t}}$ dan nilai $b^{t}$ dengan menggunakan nilai $\alpha=0.5$, maka selanjutnya dapat ditentukan prediksi jumlah penjualan papan bunga pada toko Djaya Florist dengan parameter $\alpha=0.5$ terdapat pada Tabel 4.4.

Tabel 4.4 Double Exponential Smoothing dengan $\alpha=0.5$ pada penjualan papan bunga di toko Djaya Florist

\begin{tabular}{cccccccc}
\hline $\mathbf{T}$ & $\left.\mathbf{( x}_{\mathbf{t}}\right)$ & $\left.\mathbf{( S}_{\mathbf{t}}\right)$ & $\left.\mathbf{( S}_{\mathbf{t}}\right)$ & $\boldsymbol{a}_{\mathbf{t}}$ & $\boldsymbol{b}_{\mathbf{t}}$ & $\boldsymbol{a}_{\mathbf{t}}+\boldsymbol{b}_{\mathbf{t}}$ & $\mathbf{P E}$ \\
\hline $\mathbf{1}$ & 72 & 72 & 72 & 72 & & & \\
$\mathbf{2}$ & 100 & 86 & 79 & 93 & 7 & 100 & 0 \\
$\mathbf{3}$ & 90 & 88 & 84 & 92 & 4 & 96 & 0,0666666 \\
$\mathbf{4}$ & 85 & 87 & 86 & 88 & 1 & 89 & 0,047058 \\
$\mathbf{5}$ & 70 & 79 & 83 & 75 & -4 & 71 & 0,0142857 \\
$\mathbf{6}$ & 61 & 70 & 77 & 63 & -7 & 56 & 0,0819672 \\
$\mathbf{7}$ & 74 & 72 & 75 & 69 & -3 & 66 & 0,108108 \\
$\mathbf{8}$ & 90 & 81 & 78 & 84 & 3 & 87 & 0,033333 \\
$\mathbf{9}$ & 120 & 101 & 90 & 112 & 11 & 123 & 0,025 \\
$\mathbf{1 0}$ & 80 & 91 & 91 & 91 & 0 & 91 & 0,1375 \\
$\mathbf{1 1}$ & 88 & 90 & 91 & 89 & -1 & 88 & 0 \\
$\mathbf{1 2}$ & 90 & 90 & 91 & 89 & -1 & 88 & 0,0222222 \\
$\mathbf{1 3}$ & 65 & 78 & 85 & 71 & -7 & 64 & 0,0153846 \\
\hline
\end{tabular}


JURSISTEKNI (Jurnal Sistem Informasi dan Teknologi Informasi) Vol 2, No.3, September 2020: Hal 45 - 56

ISSN. P: 2715-1875, E: 2715-1883

\begin{tabular}{lccccccc}
\hline $\mathbf{1 4}$ & 95 & 87 & 86 & 88 & 1 & 89 & 0,0631578 \\
$\mathbf{1 5}$ & 78 & 83 & 85 & 81 & -2 & 79 & 0,0128205 \\
$\mathbf{1 6}$ & 105 & 94 & 90 & 98 & 4 & 102 & 0,0285714 \\
$\mathbf{1 7}$ & 60 & 77 & 84 & 70 & -7 & 63 & 0,05 \\
$\mathbf{1 8}$ & 64 & 68 & 78 & 64 & -7 & 57 & 0,109375 \\
$\mathbf{1 9}$ & 78 & 74 & 77 & 73 & -2 & 71 & 0,0897435 \\
$\mathbf{2 0}$ & 87 & 82 & 79 & 83 & 2 & 85 & 0,022988 \\
$\mathbf{2 1}$ & 90 & 87 & 83 & 89 & 3 & 92 & 0,022222 \\
$\mathbf{2 2}$ & 75 & 80 & 82 & 80 & -1 & 79 & 0,053333 \\
$\mathbf{2 3}$ & 80 & 80 & 82 & 80 & -1 & 79 & 0,0125 \\
$\mathbf{2 4}$ & 76 & 78 & 81 & 77 & -2 & 75 & 0,013157 \\
$\mathbf{2 5}$ & 70 & 73 & 78 & 72 & -3 & 69 & 0,014285 \\
$\mathbf{2 6}$ & 72 & 72 & 76 & 72 & -2 & 70 & 0,02777 \\
$\mathbf{2 7}$ & 120 & 101 & 87 & 107 & 10 & 117 & 0,025 \\
$\mathbf{2 8}$ & 150 & 130 & 106 & 142 & 18 & 160 & 0,06666 \\
$\mathbf{2 9}$ & 60 & 88 & 99 & 85 & -7 & 78 & 0,3 \\
$\mathbf{3 0}$ & 65 & 74 & 89 & 69 & -10 & 59 & 0,09230 \\
$\mathbf{3 1}$ & 70 & 72 & 82 & 68 & -7 & 61 & 0,12857 \\
$\mathbf{3 2}$ & 75 & 74 & 79 & 71 & -4 & 67 & 0,10666 \\
$\mathbf{3 3}$ & 110 & 96 & 86 & 100 & 7 & 107 & 0,02727 \\
$\mathbf{3 4}$ & 105 & 101 & 93 & 105 & 6 & 111 & 0,057142 \\
$\mathbf{3 5}$ & 80 & 88 & 92 & 88 & -2 & 86 & 0,075 \\
$\mathbf{3 6}$ & 85 & 86 & 90 & 86 & -2 & 84 & 0,011764 \\
Jumlah & & & & & & 1,9618533 \\
\hline
\end{tabular}

Maka untuk menentukan prediksi diperiode yang akan datang digunakan rumus $\mathrm{F}_{\mathrm{t}+\mathrm{m}}=a_{t}+b_{t}$ (m).

1. Prediksi periode $37(\mathrm{~m}=1)$ yaitu untuk bulan Januari 2020 :

Yang dimana jumlah hasil nilai $a_{t}$ dijumlahkan dengan jumlah hasil $b_{t}$ pada periode $\mathrm{t}=36$ dikali dengan $(m=1)$ untuk mencari prediksi diperiode pertama, yang penyelesaiannya sebagai berikut :

$\mathrm{F}_{\mathrm{t}+\mathrm{m}}=a_{t}+b_{t} \mathrm{~m}$

$\mathrm{F}_{36+1}=\mathrm{a}_{36}+\mathrm{b}_{36}(1)$

$\mathrm{F}_{37}=86+(-2)(1)$

$=84$

2. Prediksi periode $38(\mathrm{~m}=2)$ yaitu untuk bulan Februari 2020 :

Yang dimana jumlah hasil nilai $a_{t}$ dijumlahkan dengan jumlah hasil $b_{t}$ pada periode $\mathrm{t}=36$ dikali dengan $(\mathrm{m}=2)$ untuk mencari prediksi diperiode kedua, yang penyelesaiannya sebagai berikut :

$\mathrm{F}_{\mathrm{t}+\mathrm{m}}=\mathrm{a}_{\mathrm{t}}+\mathrm{b}_{\mathrm{t}} \mathrm{m}$

$\mathrm{F}_{36+2}=\mathrm{a}_{36}+\mathrm{b}_{36}(2)$

$\mathrm{F}_{38}=86+(-2)(2)$

$=82$

Perhitungan prediksi tersebut dilakukan sampai dengan periode 48 yaitu untuk bulan Desember 2020

Berdasarkan hasil prediksi jumlah penjualan papan bunga pada tahun Januari 2020 hingga Desember 2020, maka hasil prediksi ini juga dapat disajikan kedalam bentuk grafik pada gambar berikut 


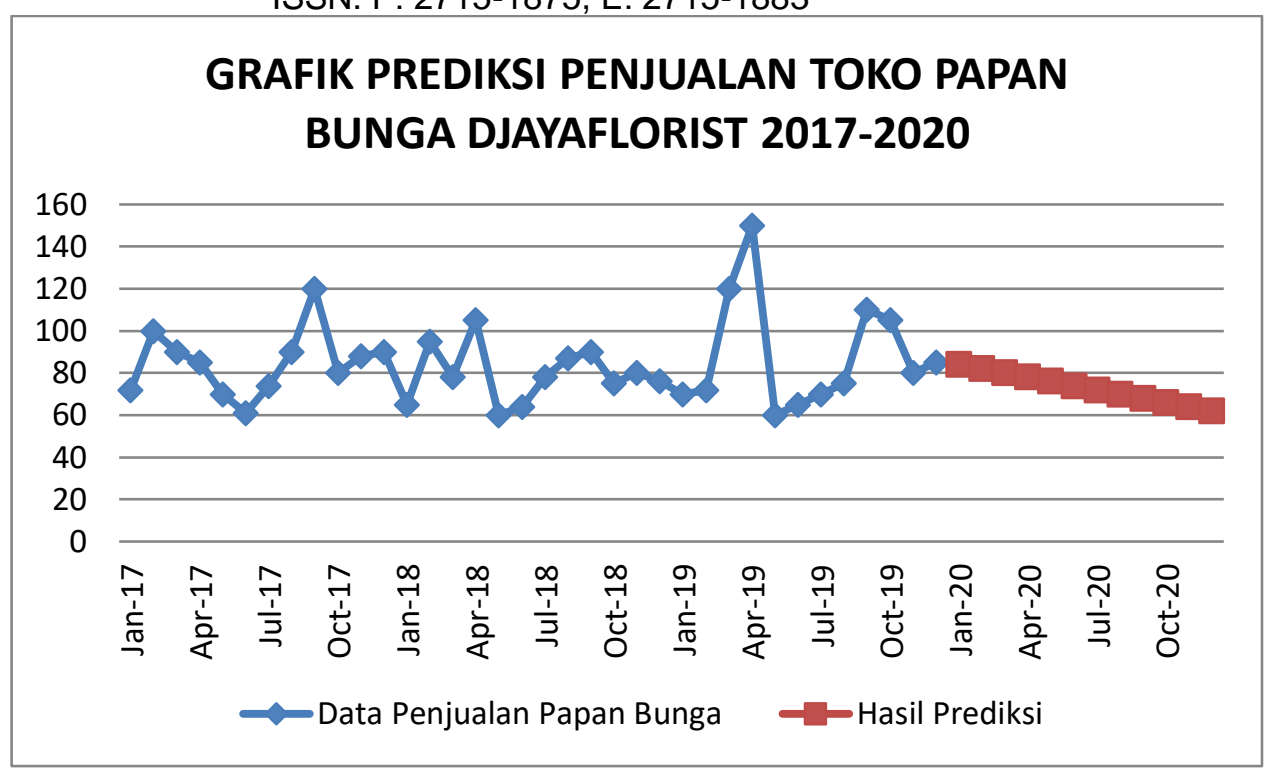

Gambar 4.2 Grafik Hasil Prediksi Penjualan Toko Papan Bunga Djaya Florist

Dari hasil prediksi yang telah didapatkan, diketahui bahwa penjualan papan bunga ditoko Djaya Florist untuk periode Januari-Desember 2020 yang akan datang mengalami penurunan setiap bulannya. Hal ini juga dapat dilihat grafik Gambar 4.2 yang menunjukkan kecendrungan pola data pada garis prediksi penjualan papan bunga pada toko Djaya Florist mengalami penurunan setiap bulannya.

\section{KESIMPULAN} kut :

Berdasarkan analisis dan pembahasan yang telah dilakukan, dapat diambil kesimpulan sebagai beri-

1. Parameter $\alpha($ alpha) terbaik yang didapat untuk prediksi penjualan papan bunga pada toko Djaya Florist dari bulan Januari 2017 sampai dengan bulan Desember 2020 adalah $\alpha=0,5$ dengan nilai MAPE sebesar 5,45\% dan dipilih dengan cara trial and error.

2. Hasil dari prediksi toko papan bunga Djaya Florist dari bulan Januari sampai dengan Desember 2020 menggunakan parameter $\alpha=0,5$ dengan menggunakan metode Double Exponential Smoothing menunjukkan bahwa toko papan bunga Djaya Florist mengalami penurunan tiap bulannya.

Dari hasil penelitian ini, penulis meyarankan agar dalam penelitian selanjutnya hendaknya menambahkan variabel - variabel lain yang mendukung prediksi penjualan papan bunga. Selain itu hendaknya menggunakan metode tambahan agar dapat menambah kevalidan hasil prediksi. Sebaiknya dalam melakukan prediksi dengan metode Double Exponential Smoothing, menggunakan data yang memiliki pola trend 


\section{DAFTAR PUSTAKa}

[1] Afiyah, S. N., \& Wijaya, D. K. (2018). Sistem Peramalan Indeks Harga Konsumen (IHK) Menggunakan Metode Double Exponential smoothing. Jurnal Ilmiah Teknologi Informasi Asia. https://doi.org/10.32815/jitika.v12i1.243

[2] Andini, T. D., \& Auristandi, P. (2016). Peramalan Jumlah Stok Alat Tulis Kantor di UD Achmad Jaya Menggunakan Metode Double Exponential Smoothing. Jurnal Ilmiah Teknologi Informasi Asia.

[3] Ariyanto, R., Puspitasari, D., \& Ericawati, F. (2017).Penerapan Metode Double Exponential Smoothing pada Peramalan Produksi Tanaman Pangan. Jurnal Informatika Polinema. https://doi.org/10.33795/jip.v4i1.145

[4] Baktiar, C., Wibowo, A., \& Adipranata, R. (2013). Pembuatan Sistem Peramalan Penjualan Dengan Metode Weighted Moving Average dan Double Exponential Smoothing Pada UD Y. Jurnal Ilmiah.

[5] Basu Swastha, D. (1998). Theory Of Planned Behaviour dalam penelitian sikap, Niat, dan perilaku Konsumen. Jurnal Ilmiah, VII, 85-103. https://journal.ugm.ac.id/jieb/article/download/39434/22323

[6] Agus Purwanto. 2017. Teknik Peramalan dengan Double Exponential Smoothing pada Distributor Gula. Bali, Indonesia : Jurnal Teknologi Informasi dan Komputer.

[7] Ahmad Nazim Aimran. 2014. A Comparison between single exponential smoothing (SES), double exponential smoothing (DES), holt's (brown) adaptive response rate exponential smoothing (ARRES) technique in forecasting Malaysia population. Malaysia : Global Journal Of Mathematical Analysis.

[8] Annastasya Lieberty. 2015. Sistem Informasi Meramalkan Penjualan Barang dengan Metode Double Exponential Smoothing. Bandung, Indonesia : Jurnal Teknik Informatika dan Sistem Informasi.

[9] Barry, Render dan Jay Heizer. 2001. Prinsip-prinsip Manajemen Operasi : Operations Management. Jakarta : Salemban Empat.

[10] Alda Raharja. 2013. Penerapan Metode Exponential Smoothing untuk Peramalan Penggunaan Wak tu Telepon di PT. Telkom Divre3 Surabaya. Surabaya. Indonesia. 